\title{
THE RAMPART AND HOT SPRINGS REGIONS.
}

\section{By Henry M. Eakin.}

\section{INTRODUCTION.}

The Rampart and Hot Springs gold-placer districts comprise the greater part of the triangular area lying between Yukon and Tanana rivers west of longitude $150^{\circ}$. The Rampart district lies north of the divide, on Minook Creek and its tributaries; the Hot Springs district includes the basins of Baker and Patterson creeks, which flow directly into the Tanana, and American Creek, which flows into Fish Lake. The region comprises also the territory lying within a few miles of the Yukon as far west as longitude $154^{\circ}$, which is included in order to cover the basins of Grant, Illinois, and Mason creeks, tributaries of the Yukon from the north below the mouth of the Tanana.

During the season of 1911 the writer made a geologic reconnaissance of the region outlined above and learned the facts here presented. This report, however, is intended to present only the results of this study that pertain to the general geology and mining activities of the region, the more intricate geologic and physiographic problems being left for treatment in a more complete report, now in preparation, which will be accompanied by geologic and topographic maps.

\section{GEOGRAPHY.}

The Rampart-Hot Springs region lies near the geographic center of Alaska, between longitudes $150^{\circ}$ and $154^{\circ}$; adjacent to Yukon and Tanana rivers, which join near its center. (See geologic sketch map, Pl. XIII.)

The drainage of the region is all tributary to the Yukon and Tanana. The largest of the secondary streams is Tozitna River, perhaps 100 miles long, which enters the Yukon from the north about 15 miles below the mouth of the Tanana. The other streams of the region are relatively small, the largest being only about 20 miles long.

The greater part of the Rampart-Hot Springs region has strong topographic relief. Elevations of 2,000 to 4,000 feet are common, 
and the valleys are usually steep sided and are carried with low gradients well back into the hills, where they head abruptly. In the lower parts of the smaller valleys and along the larger streams extensive lowlands are developed.

The climate of the region is that prevalent in the interior of Alaska, being semiarid and marked by great seasonal variations in temperature. Continuous observations for a year at Rampart and supplementary records for shorter periods indicate an annual precipitation of 11.96 inches. A longer period of observation might alter this figure somewhat, but not enough to show more than a very scanty rainfall.

The annual temperatures of the region are summarized by Brooks ${ }^{1}$ in a recent report. Concerning the interior province of Alaska, which includes the area under discussion, he says: "The average winter temperature in this province is $-5^{\circ}$ to $-10^{\circ}$, with a minimum of $-65^{\circ}$ to $-76^{\circ}$. For the summer months of June, July, and August the mean is $50^{\circ}$ to $60^{\circ}$ and the recorded maximum $90^{\circ} . "$

The open season in the Rampart-Hot Springs region commences between the 1st and the 10th of May and ends between the 1st and the 15 th of October.

Timber suitable for fuel and some suitable for lumber grows in all the valleys of the region. Spruce is the most important kind, being more widely distributed than any other and in places supplying logs that measure more than 2 feet in diameter. Cottonwood and birch are also valuable, especially near $\cdot$ Hot Springs, where the trees are unusually large. A few tamarack were noted on some of the Yukon tributaries, and willow and scrub alder thrive beside the streams and on the higher slopes. Probably four-fifths of the timbered areas have been burned over in the last decade, and the supply has been correspondingly reduced.

Agricultural products, including the ordinary vegetables and a variety of grains, are grown successfully. The Government agricultural station at Rampart is experimenting with these products with encouraging results.

The mining districts support several small settlements. Rampart on the Yukon and Hot Springs on a slough of the Tanana supply merchandise and business facilities to their respective districts. There are two other settlements in the Hot Springs district-Tofty on Sullivan Creek and Glen on a tributary of Baker Creek. A few cabins and road houses are grouped on the bank of the Yukon near the mouth of Grant Creek, of the Gold Mountain district. The largest settlement of the region is Tanana, on the right bank of the Yukon near the mouth of Tanana River. It is the connecting point

${ }^{1}$ Brooks, A. H., The Mount McKinley region : Prof. Paper U. S. Geol. Survey No. 70, 1911 , p. 199. 


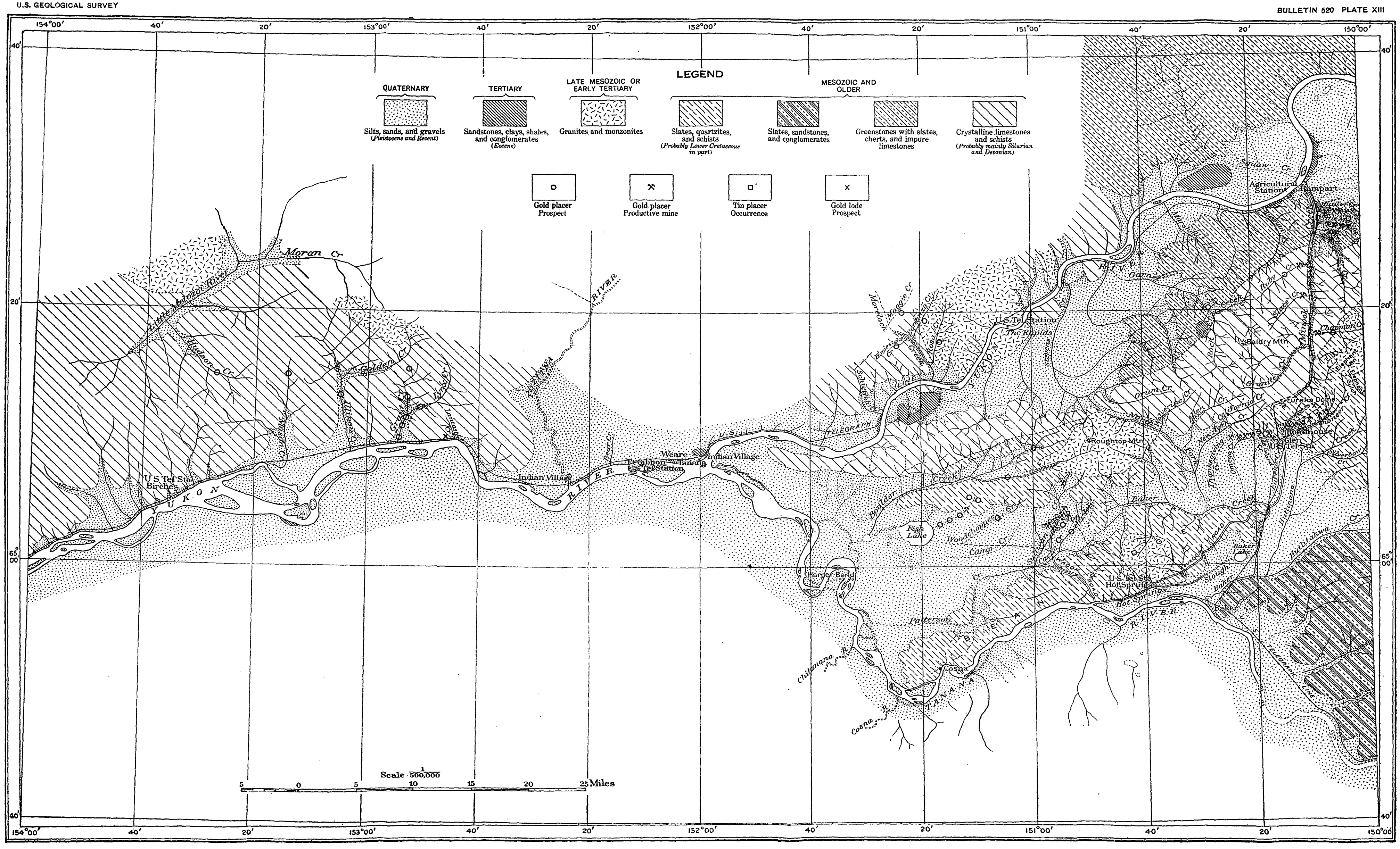

GEOLOGIC SKETCH MAP OF RAMPART AND HOT SPRINGS REGIONS. 
for the Yukon and Tanana River routes and the seat of Fort Gibbon, a United States military post.

\section{TRANSPORTATION.}

Easy access to all parts of the region is afforded by Yukon and Tanana rivers, which are navigated by a fleet of well-equipped steamboats during the open season, usually from early June to the last of September. The freight rates from Seattle depend on the nature of the commodity and the routing, as indicated in the following table:

Freight and passenger rates from Seattle to towns in Rampart-Hot Springs region.

[Based on tariffs of 1910-11.]

\begin{tabular}{|c|c|c|c|c|c|c|c|}
\hline \multirow{2}{*}{ Town. } & \multirow{2}{*}{ Route. } & \multirow{2}{*}{$\begin{array}{l}\text { General } \\
\text { merchan- } \\
\text { dise, per } \\
\text { ton. }\end{array}$} & \multirow{2}{*}{$\begin{array}{c}\text { Lumber, } \\
\text { per M. }\end{array}$} & \multicolumn{2}{|c|}{ Forage per ton. } & \multicolumn{2}{|c|}{ Passenger rates } \\
\hline & & & & Hаy. & Grain. & $\begin{array}{l}\text { First } \\
\text { class. }\end{array}$ & $\begin{array}{l}\text { Second } \\
\text { class. }\end{array}$ \\
\hline $\begin{array}{l}\text { Rampart.... } \\
\text { Tanana...... } \\
\text { Hot Springs, }\end{array}$ & 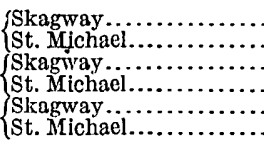 & $\begin{array}{r}\$ 82-\$ 115 \\
58 \\
84-117 \\
50 \\
89-125 \\
55\end{array}$ & $\begin{array}{r}\$ 77.50 \\
87.00 \\
79.50 \\
75.00 \\
84.50 \\
82.50\end{array}$ & $\begin{array}{r}\$ 83.00 \\
58.00 \\
85.00 \\
50.00 \\
90.00 \\
55.00\end{array}$ & $\begin{array}{r}\$ 77.00 \\
58.00 \\
79.00 \\
50.00 \\
84.00 \\
55.00\end{array}$ & $\begin{array}{l}\$ 111.00 \\
115.00 \\
115.0 \\
110.00 \\
125.00 \\
115.00\end{array}$ & $\begin{array}{r}\$ 80.10 \\
90.00 \\
81.10 \\
85.00 \\
90.00 \\
90.00\end{array}$ \\
\hline
\end{tabular}

Local freight rates from river points to the creeks vary with road conditions and the seasons of the year. In both the Rampart and Hot Springs districts some excellent roads are maintained. The rapid development of the Sullivan Creek placers within the last two years has demanded additional road improvements, which were being pushed during the summer of 1911. The summer rate on goods from Hot Springs to Tofty, a distance of 12 miles, was 5 cents a pound. and considering the difficulties of the journey this charge was not unreasonable. When the road now under construction is completed the summer rate will probably be reduced to about the present winter rate, $1 \frac{1}{2}$ cents a pound.

All the river communities are in touch with the United States military telegraph, the lines of which are shown on the map (Pl. XIII). Local telegraph lines give service in the Rampart and. Hot Springs districts. Regular United States mail service extends to all the settlements in both winter and summer.

Labor was plentiful during the summer of 1911, wages being $\$ 5$ a day and board. This amounts to a total expense of about $\$ 6.50$ a day for each man. 


\section{GENERAL GEOLOGY.}

\section{OUTLINE.}

The base of the geologic column in the Rampart-Hot Springs region is represented by a series of metamorphic rocks. Although mainly of sedimentary origin, igneous flows are common in some of its members, and locally it contains granitic intrusives. Differences in original constitution and in degrees of alteration have resulted in wide divergence between the rock types included in the series. It is probably in the main of Paleozoic age, but it may also include Mesozoic beds. The metamorphic series is overlain locally by Tertiary beds and broadly by those of Quaternary age. Granitic intrusives are distributed widely through the region in small, discontinuous areas. They are accompanied by a complex system of dikes, which are probably related to them genetically.

\section{METAIMORPHIC SERIES.}

The metamorphic series can be arranged in four lithologic divisions, each division including a different group of rock types that are constantly associated over a considerable area. The areas occupied by the several groups are distinguished on the map (Pl. XIII).

The northernmost area of the other rocks is occupied by a group of greenstones, derived from ultrabasic flows and tuffs that are mainly of a diabasic character. With these basic rocks are associated considerable areas of rhyolite and a smaller quantity of slate, chert, and impure limestone.

South of the greenstone area, between Yukon and Tanana rivers and the Gold Mountain district, are areas occupied by a more highly metamorphosed group characterized by an abundance of crystalline limestone and a variety of schists. The latter are mainly quartzite schists, but include also quartz-mica schists, garnet schist, greenstone schist, and calcareous, graphitic, and feldspathic schists. The greenstone and feldspathic schists grade into less metamorphosed types that are clearly of igneous origin. Some of the quartzose schists are apparently sheared cherty rocks, which were developed through replacement of original limestones. The micaceous and garnetiferous schists are associated with permatite dikes and quartz veins and comprise only a small part of the mass of the group.

From the foregoing description it is apparent that the limestone and schist groups have suffered both regional and contact metamorphism, and that, so far as their physical condition indicates, they are older than the greenstones and the other groups that remain to be described.

The third area of metamorphic rocks includes most of the Hot Springs district and reaches northeastward beyond the limits of the quadrangle. It is occupied by phyllites, quartzites, and schists 
less altered than the limestone-schist group and apparently overlying them.

South of the last area and occupying the big bend of Tanana River southeast of Baker Flat is the fourth group of the metamorphic rocks, which includes highly contorted red and green slates, sandstones, and fine conglomerates. ${ }^{1}$

\section{TERTIARY SEDIMENTS.}

Several small isolated areas of Tertiary sediments occur in the region adjacent to Yukon River. These rocks rest unconformably upon the various members of the older formations and yield fossil plants and invertebrates of Eocene age.

\section{QUATERNARY SEDIMENTİ.}

Unconsolidated silts and gravels mantle much of the region. The former are believed to be mainly of lacustrine origin and they are assigned provisionally to the Pleistocene epoch. The gravel deposits are of two types-a widespread deposit of variable thickness underlying the silts, and the fluviatile deposits of the modern flood plains. All of the unconsolidated sediments of the region have been included under the same pattern in mapping.

\section{IGNEOUS ROCKS.}

The oldest igneous rocks of the region are probably the flows and tuffs of the metamorphic series now altered to greenstones.

Prior to the principal deformation of the metamorphic series, extensive intrusions of granite occurred in the Gold Mountain region and farther west. These intrusions are now represented by gneisses and feldspathic schists in the prominent range of mountains that extends southwestward along the Yukon from a point near the head of Mason Creek.

At a much later period (late Mesozoic or early Tertiary) extensive intrusions of granite occurred in discontinuous areas widely scattered oyer the region, accompanied by the formation of an elaborate system of dikes, ranging in composition from granites, aplites, and acid pegmatites to gabbros and diorites.

\section{ECONOMIC GEOLOGY.}

\section{IMPORTANT IIINERALS.}

Gold is the only mineral whose occurrence in the Rampart-Hot Springs region has proved to be of economic importance. It has been mined profitably in both the Rampart and the Hot Springs districts and is known to occur at a number of other localities.

${ }^{1}$ Brooks, A. H., The Mount McKinley region: Prof. Paper U. S. Geol. Survey No. 70, 1911, p. 75. 
Tin occurs with the gold in the placers of Sullivan Creek, and small quantities have been recovered incidentally to the gold mining. So far, however, no serious attempt has been made to recover any large part of the tin ore, and only a small quantity has been shipped.

Lignitic coal occurs in the Eocene beds near Rampart, but no seams thick enough for profitable mining have been found.

\section{GOLD.}

\section{HISTORY OF PROSPECTING AND MINING.}

Placer gold was discovered in the Rampart quadrangle probably as early as 1893. The first discoveries were made on Minook Creek and its tributaries, and since 1896 systematic mining has been done in this district. Later, as the area being prospected increased, placers were located and mines developed on the tributaries of Baker. Creek along the northern border of the flats, and still later on Sullivan Creek and neighboring streams tributary to Patterson Creek.

Prospecting on the tributaries of the Yukon and Tanana west of the productive areas has revealed the presence of gold at several places. (See map, Pl. XIII). Although much ground is held on some of these streams, especially in the Gold Mountain region, the presence of gold in commercial quantities has not been demonstrated. In the Gold Mountain region this may be largely due to the facts that very little beyond annual assessment work is being done and that this work is largely of a futile character.

The scene of greatest activity in mining in the Rampart quadrangle has shifted south ward with successive discoveries. The Rampart district yielded its greatest output in 1906 and 1907. The placers along the north margin of Baker Flats reached their maximum production about the same time but have not fallen off so rapidly since. The Patterson Creek locality has steadily increased its production since operations were begun, the season of 1911 recording the largest output in its history.

Value of gold produced in the Rampart district. 
Value of gold produced in the Hot Springs district.

1902 to 1904

1904

1905

1906

1907

1908

1.909

1910

1911
$\$ 262,900$

145,500

120,000

180,000

175,000

150,000

325,000

325,000

785,000

SOURCE OF THE GOLD.

The distribution of the gold in the Rampart-Hot Springs region is definitely related to the metamorphic rocks. The bedrock in the Rampart district is the lower part of the greenstone group, which includes besides greenstones a variety of more or less altered slates, cherts, and impure limestones. The Hot Springs district, from American Creek to the Baker Creek placers, lies within the slatequartzite-schist area, and the placer ground of Quail Creek, which heads against Little Minook Creek, is a continuation of the same area.

Quartz veins are so plentifully distributed in the older rocks of the entire region that a greater abundance in the areas yielding the placers can hardly be asserted. But although as a rule the quartz veins are barren of visible mineralization, there is some evidence that in the placer districts they are gold bearing. On . Little Minook a vein 6 feet wide is said to yield gold on being crushed and panned. In the Sullivan Creek placers the richer ground is thought by the operators to be marked by an unusual abundance of quartz veins. In both districts nuggets composed partly of quartz are common. In the Gold Mountain district is a quartz vein known to be auriferous, but an unsuccessful attempt has proved that it is not of sufficient extent or richness to be mined profitably.

Although there is evidence that much of the placer gold comes from quartz veins, another source is suggested for a part of it at least in the Hot Springs region. Nuggets from What Cheer Bar near Glen include fragments of black slate. The tailings of one of the Sullivan Creek mines contained a piece of quartzite having tiny stringers of gold running along its cleavage planes. On these creeks it would appear that the gold was deposited in the available spaces in the country rock, wholly without gangue minerals. The formations comprising the country rock in all the placer districts contain members that are very rich in carbonaceous material. Carbon is believed to influence the precipitation of gold under certain conditions, and it seems possible that the distribution of gold in the region may be related in some degree to that of the carbonaceous beds. 
Still another source of gold may be the hematite deposits in the neighborhood of the granite areas near Hot Springs and Roughtop Mountain. Brecciated zones of the country rock ranging from a few inches to several feet in width have received deposits of hematite. Samples taken from these deposits in both localities are said to yield steady assay returns of several dollars a ton in gold. Although this is an unusual mode of occurrence for gold, the hematite deposits may possibly be auriferous, but further sampling, including entire crosscuts of minable bodies of the ore, will be required before their economic value will be established.

\section{AURIFEROUS GRAVELS.}

The auriferous gravel deposits of the Rampart-Hot Springs region, considered in their relation to modern topography, are of two typesstream gravels, forming the beds and flood plains of modern streams, and terrace gravels, situated above the present valley floors. Some of the terrace gravels cover benches that undoubtedly owe their origin to the present streams, but the relation of others to streams is doubtful.

\section{STREAM GRAVELS.}

The stream gravels have yielded the greater part of the production of the Rampart district, the operations on all the creeks except Hunter being confined to them. On Hunter Creek only a small part of the production has come from this source. The stream gravels of the district are shallow as a rule; on Minook Creek they are from a few feet to 15 or 20 feet thick, and on the smaller streams the range is even less, the usual thickness being about 6 or 8 feet. The gravels are usually covered with a deposit of muck and silt, which thickens as the sides of the valley are approached. It appears that the valleys were at one time more or less completely filled with silt, a large part of which has since been removed. Near the courses of the streams, where the removal has been most complete, open-cut methods are employed; but nearer the valley walls, where the overburden is very heavy, drifting becomes necessary.

In the Hot Springs district a large part of the production from the streams tributary to Baker Creek has come from the stream gravels. The deposits of this type are similar to those of the Rampart district, except that they are generally overlain by a much thinner overburden of silt or muck. The stream gravels of the Patterson Creek group have not been productive. They carry gold in small quantities, but are nowhere rich enough to be mined profitably.

\section{TERRACE GRAVELS.}

Terrace gravels occur in both the Rampart and the Hot Springs district. In the Rampart district well-defined benches occur on Minook and Hunter creeks. 
The Hunter Creek benches lie along the valley walls and may represent stages in the downcutting of the stream. The lowest bench is only 15 or 20 feet above the stream, as a rule, and has been the principal source of the gold. Its bedrock surface is irregular, in some places sloping downward away from the stream. toward the valley wall. The actual surface always slopes upward toward the margin of the valley, this being especially noticeable in the vicinity of lateral streams. The upper part of this bench deposit seems to be composed largely of materials delivered to the main valley by its tributaries in the form of alluvial fans of varying steepness. The deposits of the lower terrace of Hunter Creek are minable by opencut methods along their streamward margins, being made up, as a rule, of 3 to 6 feet of gravel, with a few feet of muck as overburden. The notable thickening of the overburden toward the margins of the valley limits the extent to which such methods are applicable.

Rather indefinite remnants of terraces occur at various elevations along the sides of Minook Valley, but only the lower bench, which resembles that of Hunter Creek, has been productive.

The ridges between the eastern tributaries of Minook Creek are peculiarly flat-topped and rise in a succession of broad steps to the eastward from 600 to 800 feet above the level of Minook Creek. In part they carry gravel deposits that have proved, locally at least, to be gold bearing. Prospecting has revealed various depths of the deposits at different places, the greatest being more than 100 feet. The materials of most of them include fragments of the local country rock, more or less worn, yellow clays or silts, and scattered quartzite bowlders, some of great size, which are foreign to the immediate neighborhood. Only very low values have been reported from these deposits, and their elevated position, even if they should prove to contain larger amounts of gold, would render their exploitation very difficult.

In the Hot Springs district bench gravels have been productive on most of the gold-bearing streams tributary to Baker Creek, and practically all of the Patterson Creek placers are in deposits that have no evident relation to the present streams.

The peculiar type of bench deposits characteristic of the Hot Springs district is illustrated by What Cheer Bar. This deposit skirts the point between Eureka and Pioneer creeks, about 250 feet above and 2,000 feet up the side of the valley from the latter stream. A space 2,000 feet long and from 150 to 200 feet wide has been mined and the resulting cut reveals the general character of the deposit. What Cheer Bar is a flattened space on a gently sloping valley side, which formerly bore auriferous gravels ranging in depth from 3 to 10 feet. The gravels range in size from fine material up to bowlders several feet in diameter. In its long direction the bench 
has no perceptible grade, but crosswise, in the direction of Pioneer Creek, it slopes at a grade which was found suitable for the sluice boxes but which is less than the general slope of the hillside. At the uphill side of the bench the bedrock rises at a steeper angle nearly to the surface and then flattens to the general slope of the hillside. The bowlders found in the deposit are mostly of quartzite with some conglomerate, both known to occur within the basin of Pioneer Creek and perhaps in the hill on which the bench is developed. Other benches that carry a little gold occur on the hillside above What Cheer Bar, and farther up the valley of Pioneer Creek on the same hillside similar deposits have been productive.

A heavy deposit of gravel occurs along the north side of Baker Flats'west of Eureka Creek, apparently unrelated in its origin to the present streams, which flow transversely across it. Although, as a rule, this deposit has proved of too low a tenor to be worked, it carries some gold and probably has been the source of much of the gold found in the gravels of the streams where they cross it.

In the Patterson Creek locality shallow gravels are worked by open-cut methods on Quartz Creek and Tofty Gulch. The deposit on Quartz Creek, known as Homestake Bar, is about a quarter of a mile from the creek on a slightly sloping hillside. It consists of 3 or 4 feet of gravels overlain by 3 feet of yellow silt. The gravels are little worn, except a thickness of about 1 foot next to bedrock. The entire hillside is covered with deposits similar to those being worked except that they carry less gold. The workable deposit extends horizontally along the hillside, and there are no surface indications to show its extent. However, the bedrock slopes at a lower angle toward the creek than the surface of the ground, and at the uphill margin it rises more sharply, forming a so-called "rim." The "rim" seems to mark the limit of the richer deposit. The ground is worked by groundsluicing and pick-and-shovel methods.

On Tofty Gulch a considerable open cut has been made on a bench on the hillside about 1,000 feet from Sullivan Creek. The deposit consisted of 4 to 6 feet of gravel covered by several feet of yellow silt and black muck. Large bowlders were very common in the top layers of the gravel, some being found in the lower part of the silt. The black muck contained a great quantity of remains of trees, which added considerably to the difficulty and expense of mining. In working the deposit the top layers of muck and silt were groundsluiced off, dynamite being employed to break up the tangle of wood débris in places, after which the gravels were carried to the sluice boxes with a steam scraper.

The other placers of Sullivan Creek and those of Cache Creek are deeper, being from 30 to 75 feet below the surface. They are worked by drifting, machinery being employed to hoist the gravel to the 
surface. The thickness of the gravel deposits ranges from 10 to 35 feet, the remaining depth being made up by an overburden of silt. At one place between Cache and Sullivan creeks a thickness of 90 feet of silt is said to have been penetrated in sinking an unsuccessful prospecting shaft. The gravels include some well-worn materials, but are mostly made up of angular fragments of the country rock. In fact, it is often difficult to distinguish the surface of the bedrock because it is so closely resembled by the fragmental deposits. One prospect hole was abandoned on reaching a lens of these deposits, but when deeper holes revealed rich gravels near by, the shaft was sunk deeper, and on reaching the true bedrock workable gravels were found.

The better worn materials are usually of the most resistant types, a hard vitreous quartzite being common. Many bowlders of this type, too large to handle, are encountered in all the drifts; in some 5-foot drifts all the vertical space is taken up by a single bowlder. However, as these bowlders are generally more or less isolated, they present no serious difficulty to the miner.

Most of the bedrock surface is considerably weathered, being brecciated and carrying gold to a depth of a foot or more. The bedrock in all the deeper mines has the form of a succession of flat benches that rise one after another toward the higher ground. The richest gravels are commonly found near the uphill margin of the benches.

The auriferous gravels of American Creek are somewhat similar to the bench gravels of the Patterson Creek locality. The later discoveries are reported to be on bench ground rather than in the stream gravels. The depths range from 10 to 20 feet. The gravels are worked by drifting, and so far no steam machinery has been used in hoisting.

On Grant Creek and some of its tributaries and on Illinois Creek, in the Gold Mountain district, good prospects are reported to have been found, but so far no valuable deposits have been discovered. Prospecting is seriously hindered by the great depth of the gravels in much of the district and by live water where they are thawed. On Illinois Creek a hole is said to have been sunk 133 feet and then abandoned, on account of live water, without having reached bedrock. The hole is said to have penetrated several beds containing a little fine gold.

On Grant Creek the results have been much the same, holes sunk from 30 to 135 feet having been abandoned on account of live water. The only holes sunk to bedrock on Grant Creek are about $2 \frac{1}{2}$ miles above its mouth and are about 30 feet deep. A few holes about 20 feet deep have been driven on Lynx Creek, the principal eastern tributary of Grant, discovering a foot of gravel on bedrock, which is said to have yielded at the rate of $\$ 10$ or $\$ 12$ a yard. After a little 
drifting had been done the works were abandoned. On American Gulch, a small tributary of Grant Creek near its head, the gravels are said to yield the best prospects found in the region, some estimates putting the values as high as $\$ 1$ a square foot of bedrock. The gravels are 10 to 12 feet deep and are thawed. The construction of a bedrock drain, which has been unsuccessfully attempted, would doubtless permit more definite knowledge of the deposit to be gained.

WATER SUPPLY.

With the exception of Minook Creek and its tributaries, Hunter and Hoosier creeks, the streams of the Rampart and Hot Springs districts afford a very scanty supply of water for mining. Hunter Creek usually furnishes water sufficient for two 3-inch nozzles under a 150-foot head; and in time of freshets, of course, the discharge is much greater. Its recorded minimum flow ${ }^{1}$ is 3.7 second-feet, or about 150 miners' inches, and its maximum, 27 second-feet, or more than 1,000 miners' inches. Hoosier Creek is very nearly the same size. Little Minook Creek carries less than a sluicehead during much of the drier part of the season.

Eureka Creek at its mouth has a discharge similar to that of Hunter Creek. About half of this is contributed by Pioneer Creek and about a fourth by the main head of Eureka above Pioneer. None of the tributaries of Patterson Creek at the locality of the mines furnishes sufficient water for constant sluicing during much of the summer, and pumping is commonly resorted to at most of the plants.

\section{MINING.}

RAMPART DISTRICT.

General statement.-Active mining in the Rampart district during 1911 was linited to Hunter and Little Minook creeks of the Big. Minook basin and Quail Creek, a tributary of Troublesome Creek. In general, a lower tenor of gravels was encountered than in former years, and the difficulties experienced in exploiting them were greater owing to an increase of the overburden as the valley walls were approached and to obstruction to the disposal of tailings due to former operations.

Hunter Creek.-On Hunter Creek two hydraulic plants were operated during the summer of 1911. A steam hoist was installed on Dawsion Creek, a tributary of Hunter, but owing to an accident was abandoned for the summer. A single claim was worked in a small

\footnotetext{
1 Covert, C. C., and Ellsworth, C. E., Water-supply investigations in the Yukon-Tanana region, Alaska, 1907 and 1908; Water-Supply Paper U. S. Geol. Survey, No. 22S, 1909, pp. 58-98; also Ellsworth, C. E., Water supply of the Yukon-Tanana region, 1909: Bull. U. S. Geol. Survey No. 442, 1910, pp. 270-281.
} 
way with pick and shovel. About 12 men were employed on four claims a part of the summer.

Little Minook Creek.-On Little Minook Creek five claims were worked to some extent during the year. The operations included winter drifting on two claims, and the use of two splash dams during the summer employing about 7 men.

Quail Creek.-This creek was not visited by the writer. It was learned, however, from the miners near Rampart that four splash dams were operated most of the summer, employing from 8 to 12 men at different times.

\section{HOT SPRINGS DISTRICT.}

General statement.-The year 1911 witnessed a marked decrease in mining operations in the part of the Hot Springs district tributary to Baker Creek contrasted with an increased activity in the Patterson Creek camp. In the former locality Thanksgiving, Omega, Pioneer, Eureka, and Hutlinana creeks were active. In the latter mining was in progress on Sullivan, Cache, Quartz, and American creeks.

Thanksgiving Creek.-In the early summer about 20 men were employed on Thanksgiving Creek at groundsluicing and shoveling in. Later in the season operations were at a.standstill owing to lack of water.

Omega Creek.-A single claim is reported to have been worked on Omega Creek in 1911, drifting and hoisting being done by hand. The ground was about 16 feet deep, and the results were said to be satisfactory.

Eureka Creek.-A steam scraper was employed in open-cut work on Eureka Creek near the mouth of Boston Creek. On the upper part of Eureka a claim was worked by means of a splash dam. Eight or 10 men were employed on this creek.

Pioneer Creek.-Four men were employed at shoveling in on the bench ground of What Cheer Bar, on the right limit of Pioneer, a little above its mouth. Two or three claims were being worked higher up on Pioneer, but were not visited. About 15 men were said to be employed in the summer workings on Pioneer.

Hutlinana Creek.-Four men operated two splash-dam outfits on the upper part of Hutlinana Creek during the summer. Nothing definite was learned of their success.

Sullivan Creek.-The greatest activity in the whole region was in the Sullivan Creek locality. Six steam hoists, employing about 150 men, were in operation most of the summer. The claims range in depth to bedrock from 30 to 70 feet, most of the overburden being yellow silt and the rest gravel and black muck.

The gold is usually in the bottom 2 or 3 feet of gravel and in the shattered bedrock. The tenor of the gravels expressed in terms of 
the area of bedrock uncovered ran from about 50 cents a square foot to more than $\$ 20$. Selected pans from the pay streak of the richest claim are reported to have carried $\$ 10$ to $\$ 15$ in gold. The tenor of the gravels actually removed ranged from about $\$ 3.50$ a yard to very much higher figures, as may be inferred from the rich pans described above.

The costs of mining vary with conditions on the different claims and the management employed. Many of the plants were compelled to pump water for sluicing, which adds considerably to the expense for fuel and cost of upkeep. The lowest estimate of the cost of operation was 35 cents a square foot of bedrock, which is equivalent to about $\$ 2.50$ a yard of gravel. Under some conditions the costs were probably double this amount.

Valuable gravels were discovered during the summer on a claim adjacent to those being worked and further prospecting will very likely disclose a still wider distribution of pay in this locality.

Cache Creek.-Three steam hoists were operated on Cache Creek in the early part of the summer, but at the time of the writer's visit two had shut down. The third plant was employing about 25 men, but had only a small amount of ground remaining to be worked. The general mining conditions are similar to those of Sullivan Creek, the pay gravel being at a depth of 50 feet and the water supply requiring the use of the pump for sluicing.

Quartz Creek.-A single plant was operating on Quartz Creek The ground is on a bench on the right limit of the creek and is shallow, allowing the use of open-cut methods. A large area had been stripped by groundsluicing off a covering of moss and about 3 feet of muck, and two men were shoveling in. The gravel deposit is from 1 to 2 feet deep and consists mostly of angular, little-worn material, except very near bedrock. Although the entire waters of the creek were diverted into the ditch they were sufficient for sluicing less than half the time. There is said to be much ground along this bench which could be profitably worked if sufficient water could be had for hydraulic mining, but which can not be worked by the more expensive hand methods.

American Creek.-Discoveries of placer gold on American Creek, a small stream,flowing into Fish Lake about 15 miles west of the Patterson Creek mines, were reported early in 1911. Active prospecting during the summer located pay gravel on at least four claims, from one of which a considerable production is reported. A hand windlass was used in hoisting the gravel, the ground being only 12 or 15 feet deep on most of the claims. Thirty to 50 men were on the creek most of the summer and preparation was being made for extensive work in both prospecting and mining during the winter. 
TIN.

Smoothly rounded pebbles of cassiterite, the oxide of tin, occur in the placers of the Sullivan Creek group in company with the gold. The neighboring placers on Cache and Quartz creeks are barren of the mineral, so that the area in which it occurs is small, being less than a mile in its longest direction. In quantity, the tinstone or stream tin, as it is commonly called, varies with the gold, the placers commonly being rich or lean in both minerals. In the richest spots as much as half a pound of tin to the pan is reported, which at the present price of the ore would give the gravels a value, not allowing for costs of mining or transportation, of $\$ 18$ to $\$ 20$ a yard, according to assay.

Gravels that contain as little as 9 pounds of cassiterite to the yard are being profitably mined in the York region, Alaska. There can be little doubt that a great part of the gravels mined on Sullivan Creek carry as high a content of tin and that some may run much higher. But on account of the inconvenience that the presence of the tin ore occasions in the separation of the gold it is deemed a nuisance by the miners of the district rather than a possible resource.

The bedrock source of the tin has been the subject of a great deal of speculation, and considerable effort has been spent in trying to locate it. The search has been made in the region around Roughtop Mountain rather than the neighborhood of the placers, under the impression that only an area of igneous rock could supply the mineral. Although it is true that in its typical occurrence in bedrock there is an evident relation of the ore to some igneous rock from which the tin-bearing solutions probably emanated, cassiterite may also occur in quartz veins and small dikes at some distance from any large igneous mass. There is a strong likelihood that the tin of the placers has not been brought a great distance to its present position but that it has been derived from veins and dikes of the country rock that have been eroded from the same area in which the tin-bearing placers are found. Bedrock prospecting in the vicinity of the mines is difficult, owing to the thick covering of gravel and silt. A closer scrutiny of the bedrock exposed in the mines and in the neighboring hills is desirable, especially of the quartz veins and micaceous dikes, which may possibly be tin bearing. Should any angular and littleworn cassiterite be found in the gravels it would be good evidence of a bedrock deposit near at hand. That the quartz veins of the Sullivan Creek area are probably the source of the tin as well as of a large part of the gold is indicated in the structure of the ore, which is in the form of a recemented breccia. The fragments composing the breccia are vein quartz; the cementing material is principally cassiterite. Blue and brown tourmaline and small quantities of fluorite 
also fill spaces between the quartz fragments in some of the specimens. From this structure it is inferred that the quartz veins were originally formed barren of the other minerals along the joint planes of the country rock, and that subsequent dynamic stresses caused movement along these planes and the brecciation of the quartz veins. These stresses were possibly due to the injection beneath the region of an igneous mass which may have furnished the tin-bearing emanations from which the ores were derived. 